\title{
Self-Acceptance of Chronic Caused Failure Patients That Have a Hemodialysis in Medan
}

\author{
Cholina Trisa Siregarl, Mia Rhamayani ${ }^{2}$
}

${ }^{1,2}$ Faculty of Nursing Universitas Sumatera Utara

\begin{abstract}
Chronic kidney failure patients undergoing hemodialysis undergo physical and psychological changes. Self-acceptance is a person's ability to have a realistic assessment of advantages and disadvantages. This study aims to describe self-acceptance in patients with chronic renal failure undergoing hemodialysis in the RSUD Dr. Pirngadi Medan. The study population was patients with chronic renal failure who underwent hemodialysis at the RSUD Dr. Pirngadi Medan. The sample of this study amounted to 106 people. The sampling technique uses non probability sampling, namely, purposive sampling. The inclusion criteria for the study sample were chronic kidney failure patients who underwent hemodialysis who were in consciousness compos mentis. Data collection was conducted in April-May 2017. Data were analyzed by descriptive statistical analysis. The results of the study obtained data that 12 people were at high self-acceptance $(11.3 \%), 80$ people were at moderate self-acceptance $(75.5 \%)$, and 14 people were at low self-acceptance $(13.2 \%)$. Based on the results of the study it can be concluded that patients with chronic renal failure undergoing hemodialysis in the RSUD Dr. Pirngadi Medan has a good self-acceptance, ie the patient accepts his condition even though he has to undergo hemodialysis for life. Researchers expect that nurses can provide emotional support and motivation to patients to improve patient self-acceptance.
\end{abstract}

Keyword: self-acceptance, chronic kidney failure, hemodialysis.

Received 04 February 2019 | Revised 14 May 2019| Accepted 26 January 2019

\section{Introduction}

The human body consists of various systems, including the urinary system. In the urinary system, there is a blood screening process carried out by several organs, one of which is the kidney (Chandrasegaran, 2013). The kidneys have important functions for the body, if the kidneys are not able to carry out their functions such as filtering excess fluid and blood waste, then the individual will experience a balance of homeostasis in the body (Sridianti, 2016).

Chronic kidney failure is a late stage kidney disease whose incidence continues to increase every year, both in developed and developing countries, this condition is caused by the increasing number of occurrences of the main causes of chronic kidney failure such as

\footnotetext{
${ }^{*}$ Corresponding author at: Jl. Prof.Maas No. 03 Kampus USU, Medan, Indonesia 
glomerulonephritis, diabetes mellitus and hypertension (Zhang \& Rhothenbacher, 2008). United State Renal Data System (USRDS) (2015) reported that the prevalence of chronic kidney failure in the United States in 2013 reached 661,648, where there was an the number of patients with chronic kidney failure was based on a doctor's diagnosis of $0,2 \%$ of the population (Riskesdas, 2013).

Patients with chronic kidney failure need kidney replacement therapy to maintain bodily functions. Kidney replacement therapy that can be done by patients with chronic kidney failure is dialysis and kidney transplantation (Nicolas, 2013). The Indonesian Renal Registry (IRR) (2011) says that hemodialysis is the most widely used dialysis therapy with a percentage of 78\%. In North Sumatra, the number of new hemodialysis patients in 2014 was 680 and 329 were active hemodialysis patients (IRR, 2014). Medical record data at Dr. Pirngadi Medan in 2013 stated that the number of patients with chronic kidney failure who underwent hemodialysis was 184 people (Hayani, 2014).

During the hemodialysis process, patients generally experience physical stress, feel fatigue, headaches, and cold sweats due to decreased blood pressure (Supriyadi, Wagiyo, \& Widowati, 2011). If hemodialysis is not carried out regularly (according to schedule), the patient's health will decrease (Situmorang, 2015). Patients will lose freedom, depending on health services, division in marriage, family, and social life, and reduced or loss of income (Nurchayati, 2010).

Rasmun (2004) said that the state of dependence on a lifetime dialysis machine and adjustment to the condition of the illness resulted in changes in the life of the patient. Changes that occur include psychological, physical, activity and spiritual changes (Asti, Hamid, \& Putri, 2014). According to Winasis (2009) changes in patients who view themselves negatively can aggravate the pain they experience. These changes can trigger stress (Rasmun, 2004). Stress can worsen a patient's health so that it will affect the quality of life (Hawari, 2008).

In the midst of treatment of chronic kidney failure with hemodialysis that must be done for life, patients experience several pressing problems. Lukman, Kanine, and Wowoling (2013) said that they usually experience financial problems, difficulties in putting up work, sex drive, and the most common problems are anxiety and depression.

The ways, attitudes or reactions of individuals in dealing with their illnesses vary and are very subjective in nature. This depends on how far the individual's ability to adjust to life threatening situations (Lubis, 2009). In some individuals who suffer from a disease, psychological disorders may occur and will experience personal growth if the patient has good self-acceptance. Emotional conditions such as feelings of happiness, feelings of sadness or anxiety and individual life satisfaction can affect individual self-acceptance.

Self-acceptance is considered an important feature of mental health and also as a characteristic of self-actualization and calmness. According to Anderson (in Sugiarti, 2008: 6) self-acceptance is very influential on how a person goes through life. Someone who is able to accept himself, 
then he will not be afraid to see himself honestly, both inside (heart / mind / feeling) and outside (behavior, appearance), because we cannot run away from ourselves, even if we do anything. This self-acceptance is needed to unite body, mind and spirit. Based on this phenomenon researchers are interested in conducting research on self-acceptance in patients with chronic renal failure undergoing hemodialysis in Medan.

\section{Research Methods}

The research design used in this study is descriptive, namely the method of research carried out with the main aim of making a description of an objective situation, in this case to describe selfacceptance in patients with chronic renal failure undergoing hemodialysis in Medan. The population in this study were all patients with chronic kidney failure who underwent hemodialysis in the hemodialysis unit of Dr. Hospital. Pirngadi Medan. The sample in this study is total sampling (120 people). But at the time of the research, the researchers only got 106 people who were willing and participating to become research respondents. 14 people refused by reason of not wanting to, feeling unwell, wanting to go home soon, and having difficulty hearing. Thus, the number of samples in this study was 106 people.

The sampling technique in this study was conducted using non probability sampling techniques, namely, by means of purposive sampling. The samples taken in this study must meet the inclusion criteria, namely, patients with chronic renal failure who undergo hemodialysis, are in a compos mentis consciousness. Whereas the exclusion criteria in this study were that chronic renal failure patients undergoing decreased hemodialysis during the study took place so that it was difficult to fill in the research instruments. The instrument in this study used a questionnaire covering demographic data consisting of gender, age, marital status, recent education, occupation, duration of chronic kidney failure, frequency of hemodialysis per week, and involvement of family or closest people during hemodialysis, as well as consists of 15 statRespondent Demographic Characteristics.

\section{Research Result}

The demographic characteristics of the respondents consisted of gender, age, marital status, recent education, occupation, duration of chronic kidney failure, frequency of hemodialysis every week, and involvement of family or closest people during hemodialysis. The results of this study were that respondents with male sex were more than women, that is, 62 people (58.5\%), the age range of the respondents was mostly between the ages of 41-60 years, that is, 73 people (68.9\% ), the majority of respondents have married as many as 99 people (93.4\%), the last education of the respondents was mostly at the high school level, 47 people (44.3\%), more than half of the respondents did not work, 66 people $(62.3 \%)$, the majority of respondents have suffered chronic kidney failure $\geq 1$ year, that is, 95 people $(50 \%)$, all respondents did $2 \mathrm{x}$ hemodialysis per week, that is, 105 people (99.1\%), and 62 respondents $(58.5 \%$ ) accompanied by family or closest people while undergoing hemodialysis. 
Demographic characteristics of respondents can be seen in Table 1.1.

Table 1. Frequency Distribution and Percentage of Demographic Characteristics of Respondents of Chronic Kidney Failure that Undergo Hemodialysis Medan $(n=106)$

\begin{tabular}{|c|c|c|}
\hline Demographic & (f) & $(\%)$ \\
\hline $\begin{array}{l}\text { Gender } \\
\text { Man } \\
\text { Women }\end{array}$ & $\begin{array}{l}62 \\
44\end{array}$ & $\begin{array}{l}58,5 \\
41,5\end{array}$ \\
\hline $\begin{array}{l}\text { Age } \\
18-40 \text { years old } \\
41-60 \text { years } \\
>60 \text { years old } \\
\end{array}$ & $\begin{array}{l}23 \\
73 \\
10 \\
\end{array}$ & $\begin{array}{c}21,7 \\
68,9 \\
9,4 \\
\end{array}$ \\
\hline $\begin{array}{l}\text { Marital status } \\
\text { Married } \\
\text { Single } \\
\text { Widow }\end{array}$ & $\begin{array}{c}99 \\
6 \\
1\end{array}$ & $\begin{array}{r}93,4 \\
5,7 \\
0,9\end{array}$ \\
\hline $\begin{array}{l}\text { Last education } \\
\text { Elementary school } \\
\text { Junior high school } \\
\text { High school } \\
\text { Diploma } \\
\text { Bachelor }\end{array}$ & $\begin{array}{c}14 \\
23 \\
47 \\
5 \\
17\end{array}$ & $\begin{array}{c}13,2 \\
21,7 \\
44,3 \\
4,7 \\
16\end{array}$ \\
\hline $\begin{array}{l}\text { Work } \\
\text { Government employees } \\
\text { Private } \\
\text { Does not work }\end{array}$ & $\begin{array}{l}14 \\
26 \\
66\end{array}$ & $\begin{array}{l}13,2 \\
24,5 \\
62,3 \\
\end{array}$ \\
\hline $\begin{array}{l}\text { Long Suffered from CRF } \\
>1 \text { year } \\
\geq 1 \text { year }\end{array}$ & $\begin{array}{l}11 \\
95 \\
\end{array}$ & $\begin{array}{l}10,4 \\
89,6\end{array}$ \\
\hline $\begin{array}{l}\text { Frequency. Hemodialysis / week } \\
2 \mathrm{x} / \text { week } \\
1 \mathrm{x} / \text { week }\end{array}$ & $\begin{array}{c}105 \\
1 \\
\end{array}$ & $\begin{array}{c}99,1 \\
0,9 \\
\end{array}$ \\
\hline $\begin{array}{l}\text { Accompanied by family } \\
\text { Yes } \\
\text { Not }\end{array}$ & $\begin{array}{l}62 \\
44\end{array}$ & $\begin{array}{l}58,5 \\
41,5 \\
\end{array}$ \\
\hline
\end{tabular}

The results of this study obtained data that the self-acceptance of patients with chronic renal failure undergoing hemodialysis in RSUD Dr. Pirngadi Medan who became the research respondent was mostly at moderate self-acceptance namely, as many as 80 of 106 respondents $(75.5 \%)$. Respondents who have high self-acceptance are 12 people (11.3\%) and low self-acceptance as many as 14 people (13.2\%). Data on the results of research on self-acceptance in patients with chronic renal failure undergoing hemodialysis in RSUD Dr. Pirngadi Medan can be seen in Table 1.2. 
Table 2. Frequency Distribution and Percentage of Self-Acceptance in Chronic Kidney Failure Patients Undergoing Hemodialysis in Medan $(\mathrm{n}=106)$

\begin{tabular}{|l|c|c|}
\hline \multicolumn{1}{|c|}{ Self-acceptance } & (f) & $(\%)$ \\
\hline High & 12 & 11,3 \\
Moderate & 80 & 75,5 \\
Low & 14 & 13,2 \\
\hline
\end{tabular}

\section{Research Discussion}

The results of this study obtained data that the picture of self-acceptance in patients with chronic renal failure undergoing hemodialysis in the RSUD Dr. Pirngadi Medan as many as 80 out of 106 respondents are at the level of self-acceptance with a percentage of $75.5 \%, 12$ people (11.3\%) have high self-acceptance, and 14 people (13.2\%) have low self-acceptance.

Self-acceptance is one of the factors that determine one's well being (Ryff, 1989). Sustainable being does not require individuals to feel good all the time. The experience of painful emotions such as disappointment, failure and grief is a normal part of life, and being able to regulate these negative emotions is important for long-term well being.

According to Ross (1998) before someone accepts the situation that happened to him, the person first experiences anger phase in him. Individuals who accept themselves have realistic expectations of their situation and respect themselves. According to Hurlock (in Sugiarti, 2008) when someone has realistic expectations in achieving something, then his behavior will appear in accordance with his expectations. This will affect self satisfaction which is the essence of self-acceptance.

Individuals with high levels of self-acceptance generally have a number of amazing qualities. High self-acceptance can be influenced because they get good social support. Someone who gets support from the social environment will make the person feel more accepted by the environment so that they will be able to accept themselves better (Sari, 2002). This individual will be better able to control his emotions and face various events in life better. While individuals with low self-acceptance view their lives as low and consider events that occur as unpleasant things such as anxiety, depression, and anger (Diener \& Suh, 2000).

Research by Riskiana and Setyawati (2014) stated that this self-acceptance then determines the process of solving the problems faced by patients with positive 
management. If the patient has a life acceptance and social support from the family and community environment, the patient tends to have a more positive strategy and problem management.

Social support is significantly positively related to self-acceptance in patients with kidney failure. The more positive social support received by patients with kidney failure, the higher their self-acceptance will be, or the more negative the social support received by the patient fails, the lower their acceptance.

Self-understanding and self-acceptance are two things that go hand in hand. The more a person understands himself, the better his acceptance. According to Hurlock (1976) people who can accept themselves will be able to adjust themselves well. Good selfacceptance will have high happiness characterized by having goals in life, having positive or pleasant emotions, patients feeling comfortable, happy, and warm because of familiarity with other patients and nurses, having focused attention when doing activities, feeling late, and engrossed in work or activities, and forget about the disease and limitations.

Conversely, patients with poor self-acceptance will feel unhappiness. They often compare themselves with other people who do not have chronic diseases such as themselves who have limited work. They feel a burden in the family even though they are the heads of the family who are obliged to provide for their care, therefore they are not comfortable in living, lacking enthusiasm, and feel that their lives are meaningless. Patients who have high self-acceptance but low happiness, they do not care about the words of others about the lives of those who have kidney failure, they still feel valuable without comparing themselves with others.

\section{Conclusion}

Good self-acceptance does not mean that patients do not feel negative affect at all but fewer patients feel negative affect and more often feel positive affect and are satisfied with the life they live. Respondents who often feel positive affect usually get support from family or closest people such as being accompanied during hemodialysis. It will be able to provide good coping for respondents.

\section{REFERENCES}

[1] Asti, A. D., Hamid., A. Y. S., \& Putri, Y. S. E. (2014). Gambaran perubahan hidup kliengagal ginjal kronis yang menjalani hemodialisa. Jurnal Kebidanan dan Keperawatan, Vol. 10, No. 2, 172-185. 
[2] Chandrasegaran, K. (2013). Gambaran nilai international prostate symptom score pada pasien benign prostate hyperplasia di poliklinik urologi rsup haji adam malik medan. Kuliah Tulis Ilmiah.

[3] Diener, E. \& Suh, E.M. (2000). Culture and subjective well being. MIT Press. Hawari, D. (2008). Manajemen stres, cemas, dan depresi. Jakarta: FKUI.

[4] Hayani, N. (2014). Hibungan dukungan sosial dengan tingkat depresi pasien gagal ginjal kronik yang menjalani hemodialisis di rsud kota medan. Tesis.

[5] Hurlock, E. (1976). Addolescent development. Tokyo: Mc Graw Hill Kogakusha Ltd.

[6] Lubis, N.L. (2009). Depresi: tinjauan psikologis. Jakarta: Kencana Prenada Media Group.

[7] Lukman, N., Kanine, E., \& Wowiling, F. (2013). Hubungan tingkat hemodialisa dengan tingkat depresi klien penyakit ginjal kronik di rsup prof. dr. rd kandou manado. $E$ Journal Keperawatan, Vol. 1, No. 1.

[8] Nurchayati, S. (2010). Analisis faktor-faktor yang berhubungan dengan kualitas hidup pasien penyakit ginjal kronik yang menjalani hemodialisa di rsi fatimah cilacap dan rsud banyumas. Diunduh 27 Oktober 2016, dari http://lontar.ui.ac.id/file?file=digital/20282431...pdf.

[9] Rasmun. (2004). Stres, koping, dan adaptasi: teori dan pohon masalah keperawatan. Jakarta: Sagung Seto.

[10] Ryff, C.D. (1989). "Happiness is everything, or is it? explorations on the meaning of psychological wellbeing". Journal of Personality and Social Psychology. 57, 10691081.

[11] Sari, E.P. \& Nuryoto, S.(2002) Penerimaan diri pada lanjut usia ditinjau dari kematangan emosi. Jurnal Psikologi. Universitas Gajah Mada. No.2 Hal. 73-88.

[12] Situmorang, H. E. (2015). Hubungan dukungan keluarga dengan kualitas hidup pasien gagal ginjal kronis yang menjalani hemodialisa di rsud dok II jayapura. Jurnal Ilmu Pendidikan Indonesia, Vol. 3, No. 3, 23-30.

[13] Supriyadi, Wagiyo, \& Widowati, S. R. (2011). Tingkat kualitas hidup pasien pgk yangmenjalani terapi hemodialisa. Diunduh 27 Oktober 2016, dari journal http://unnes.ac.id/index.php/kemas.

[14] Indonesian Renal Registry. (2014). Indonesia: Pernefri. (2011). Indonesia: Pernefri.

[15] United State Renal Data System. (2015). Amerika Serikat: USRDS.

[16] Winasis, E. B. (2009). Hubungan antara konsep diri dengan depresi pada penderita diabetes mellitus di puskesmas pracimontoro 1 wonogiri. Skripsi.

[17] Zhang, Q. \& Rothenbacher, D. (2008). Prevalence of chronic kidney disease in population studies: systematic review. BMC Public Health, Vol. 8, No. 117. Diakses 27 Oktober 2016, dari http://www.biomedcentral.com/1471-2458/8/117 